\title{
Capturing the sustainability agenda: organic foods and media discourses on food scares, environment, genetic engineering and health
}

\author{
Associate Professor Stewart Lockie \\ Director \\ Centre for Social Science Research \\ Central Queensland University \\ Rockhampton QLD 4702 \\ AUSTRALIA \\ Ph: +61-7-49306539 \\ Fax: +61-7-49306402 \\ Email: s.lockie@cqu.edu.au
}

Re-submitted to Agriculture and Human Values, April 2005.

Stewart Lockie is Associate Professor of Rural and Environmental Sociology and Director of the Centre for Social Science Research at Central Queensland University. His main research interests lie in the greening of food and agriculture, food commodity networks and natural resource management. Recent co-edited books include Rurality Bites: The Social and Environmental Transformation of Rural Australia and Consuming Foods, Sustaining Environments.

\section{Acknowledgements}

The author would like to thank Nell Salem for her invaluable assistance in the collection and processing of data for this paper, along with the rest of the Greening Foods research team, Professor Geoffrey Lawrence and Dr Kristen Lyons. 


\title{
Capturing the sustainability agenda: organic foods and media discourses on food scares, environment, genetic engineering and health
}

\begin{abstract}
This paper undertakes a content analysis of newspaper articles from Australia, the UK and the US concerned with a variety of issues relevant to sustainable food and agriculture during the period 1999 to 2002. It then goes on to identify the various ways in which sustainability, organic food and agriculture, genetic engineering, genetically modified foods and food safety are framed both in their own terms and in relation to each other. It finds that despite the many competing approaches to sustainability found in scientific and agricultural production discourses, media discourses tend to reduce this complexity to a straightforward conflict between organic and conventional foods. Despite regular reporting of viewpoints highly critical of organic food and agriculture, this binary opposition produces discourses in which organic foods are seen as more-or-less synonymous with safety, naturalness and nutrition, and their alternatives as artificial, threatening and untrustworthy. Particularly controversial food-related issues such as genetic engineering, food scares, chemical residues, regulatory failure and so on are thus treated as essentially part of the same problematic to which organic food offers a trustworthy and easily understood alternative.
\end{abstract}

\section{Keywords}

Organic food, genetic engineering, discourse, content analysis

\section{Introduction}

It is widely acknowledged that despite almost universal acceptance of the importance and desirability of environmental and social sustainability, the concept of sustainability itself is a slippery and contested one (Barr and Cary, 1994). Conflicting ideas about what a safe and sustainable food system might look like are evident in debates over organic food standards, genetic modification, food labelling, chemical safety guidelines, agricultural research priorities, tree clearing, food safety standards, quality assurance processes, property rights, pesticide regulation, appropriate levels of public investment in agri-environment schemes, and so on. They are also reflected in what Lockie et al. (2002) identify as high levels of confusion among Australian consumers regarding the social and environmental attributes of foods produced and processed according to a variety of regulatory regimes and the ability of these foods to alleviate consumers' own food-related concerns and anxieties. Such confusion has promoted, among many consumers, a sense of ambivalence and powerlessness 
regarding the extent to which their own food choices may make a difference to themselves, others or the environment (see also Lockie, 2002).

This paper is not concerned with the evaluation of competing claims to sustainability but with the identification of major themes and trends in mass media representation of issues related to food, environment and health. It would be simplistic, of course, to draw any direct causal inferences, in either direction, between media reporting and public understanding and attitudes. Nevertheless, mass media representations of foodrelated issues do provide a useful foci through which to analyse the ways in which words, symbols and meanings are deployed in bids to influence others and thus to order, or structure, food production-consumption networks. In light of claims that 'consumer demands' are driving the growth of a variety of quality assurance programs and alternative food networks (Lockie, 2002) it is particularly pertinent to examine the wider discursive fields in which these 'demands' are articulated. Before doing so, the paper will turn briefly to an articulation of the key methods and concepts on which it draws.

\section{Methodology and key concepts}

The data presented in this section were drawn principally from a content analysis of the Chicago Tribune, the New York Times, The Times (London), and all major Australian national and state newspapers as defined by the Nexus indexing service. Newspaper selection was based both on the desire to attain a degree of international comparability and the pragmatic need to limit coverage to English language newspapers available through the Central Queensland University subscription to the Nexus indexing service. As a result, it must be acknowledged that while the Australian sample covers a wide spectrum of publications and associated readerships, the UK and US samples are biased towards broadsheet newspapers. While intuitively one might expect broadsheet newspapers to offer more extensive coverage and greater depth of analysis of issues such as food and sustainability, a review of the Australian publications demonstrates that this is not necessarily the case with a large number of relevant feature articles appearing in tabloid newspapers.

The sampling period for this analysis was January 1996 to December 2002. Searches were performed on a variety of terms including organic food, organic agriculture, agriculture and environment, food and environment, genetic engineering, genetically modified foods and food scares. All articles identified using these search terms were downloaded and screened to ensure they matched the intended meaning of the search criteria. This process resulted in a database of over 9,000 usable articles. Analysis was then conducted of: first, the prevalence of each search term and how this had changed over the sampling period; and second, the key themes to emerge in relation to the greening of food networks and the manner in which these were framed.

Framing here refers to the repetitive use of particular ways of presenting information that help the reader, viewer or listener interpret the meaning and significance of that information (Hannigan, 1995). Frames provide principles for selecting, emphasising and presenting information that leave unstated any number of assumptions and theories about what is important and why (Gitlin, 1980, cited in Miller and Riechert, 2000). According to Miller and Reichert (2000: 45), framing allows journalists to 
focus on the apparently objective and balanced presentation of facts and to stillwhether consciously or unconsciously-contribute to the pursuit of particular political projects. By reducing complex issues to series of largely unrelated events-but presenting those events in the context of familiar storylines - the need to provide indepth analysis is significantly reduced (Hannigan, 1995). Framing devices include metaphors, examples, catch-phrases, depictions and visual images, and may be accompanied by reasoning devices including the causes of events, their consequences, and appeals to principles (Hannigan, 1995).

The deployment of framing devices does not, of course, guarantee either that audiences will interpret their content in the intended manner or that this content will influence their attitudes or behaviour. Communication is non-linear and audiences bring their own, variable, frames to bear on the interpretation of information. However, this does not mean that textual meaning is either 'radically indeterminate' or insignificant (Corner and Richardson 1993: 229). Media frames reflect, and contribute to, discourses that extend beyond the immediate textual content of the newspaper or broadcast. Discourses are ways of 'talking about something, organising knowledge and thereby classifying and regulating people' that come to be established as accepted knowledge (Haralambos et al., 1996: 159). While discourses are contestable and potentially unstable, they contribute to the reproduction of networks by helping participants make sense of social relationships (Law, 1994); that is, by linking words and symbols with power, knowledge and expertise (Foucault, 1980). Thus, the prevalence, relatively high level of organization, and appeals to objectivity and authority of media content renders analysis of the frames through which it is organized a useful entry point in the exploration and analysis of public discourses (Corner and Richardson, 1993) and an equally useful adjunct to research on social movement mobilizations, regulatory practices, public opinions, and other aspects of food and sustainability politics.

\section{Prevalence of food scare and sustainability signifiers}

The prevalence of articles concerned with different aspects of the sustainability of food networks has changed dramatically over the last ten years. Despite the development of sizable sustainable agriculture movements, programs and research initiatives over several decades, prior to 1996, very few articles of any aspect of sustainability found their way into any of the publications included in this analysis. Even over the period 1996 to 2002, there were some aspects of sustainability that still did not attract significant media attention. Searches on agriculture and environment and food and environment uncovered few articles concerned with the biological and physical environment rather than the market, business or regulatory environment for food production. Those articles that were found were framed in terms of impending environmental crisis as a result of salinity, water shortages and land clearing (see also Vanclay, 1992). Very few made mention of alternative or innovative agricultural practices that may help to avert or manage these crises. Farmers and governments were represented either as victims or villains, but there was no mention of how consumers, agribusinesses and other participants in agri-food networks contribute to environmental threats. 
Figures 1 to 5 show results of the other searches. Caution should be exercised in drawing conclusions based on differences in the number of articles attributed to each source for any one search term since the categories used are a combination of single publications and groups of publications. Trends in the numbers of articles published over time for each source-and differences in the number of articles published on each topic - are more reliable indicators of the relative prominence of the various greening issues over time.

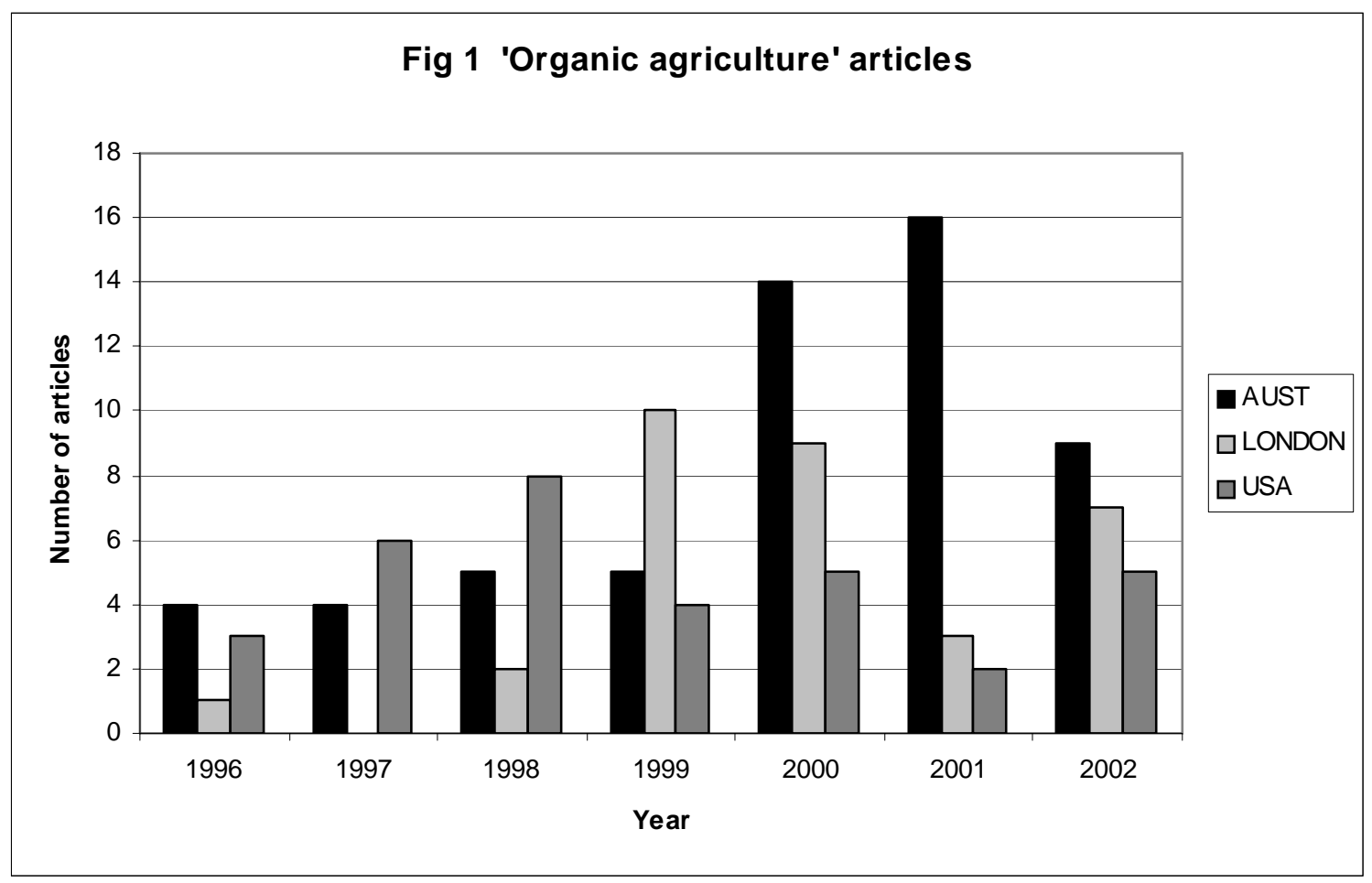



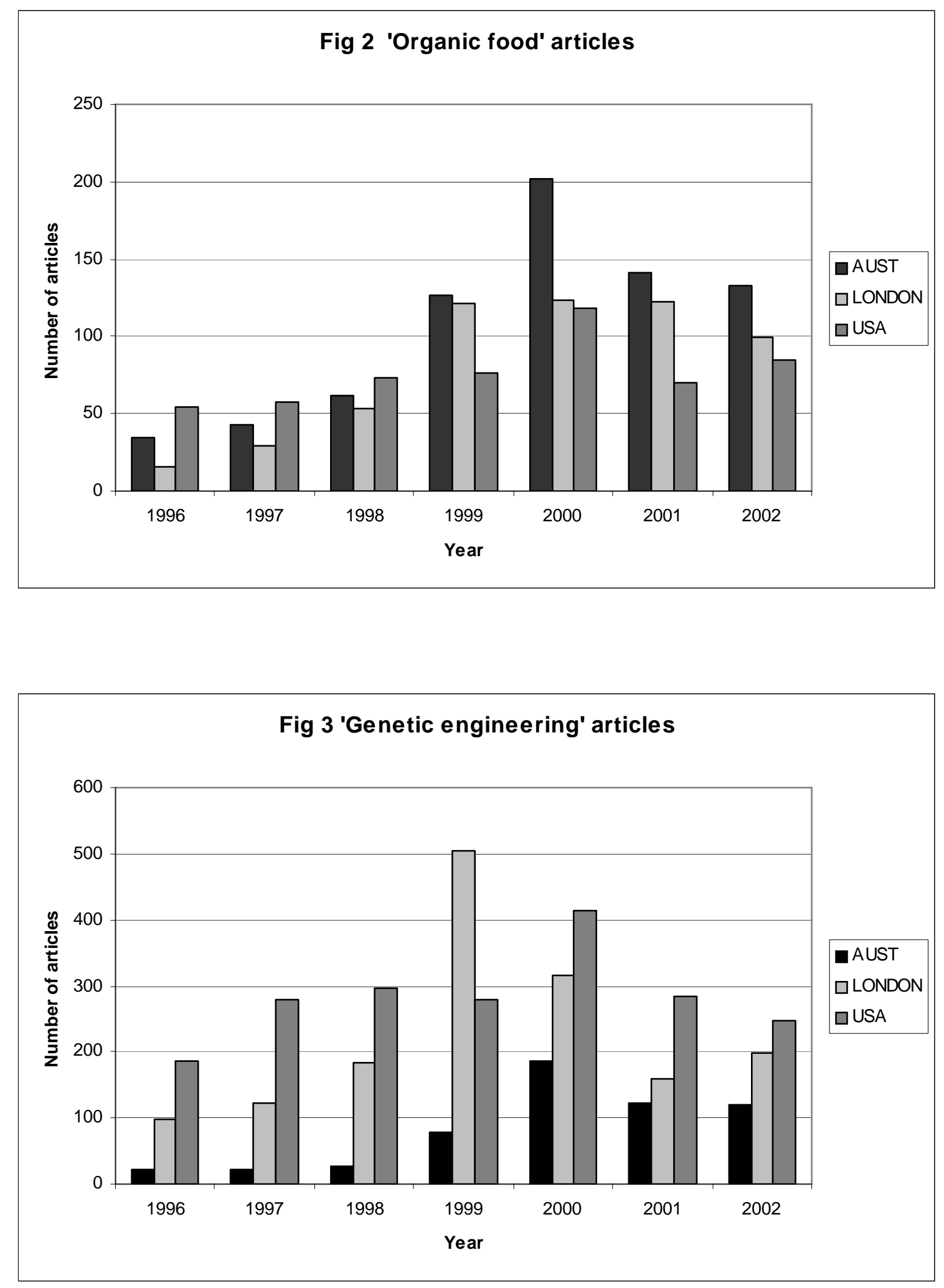

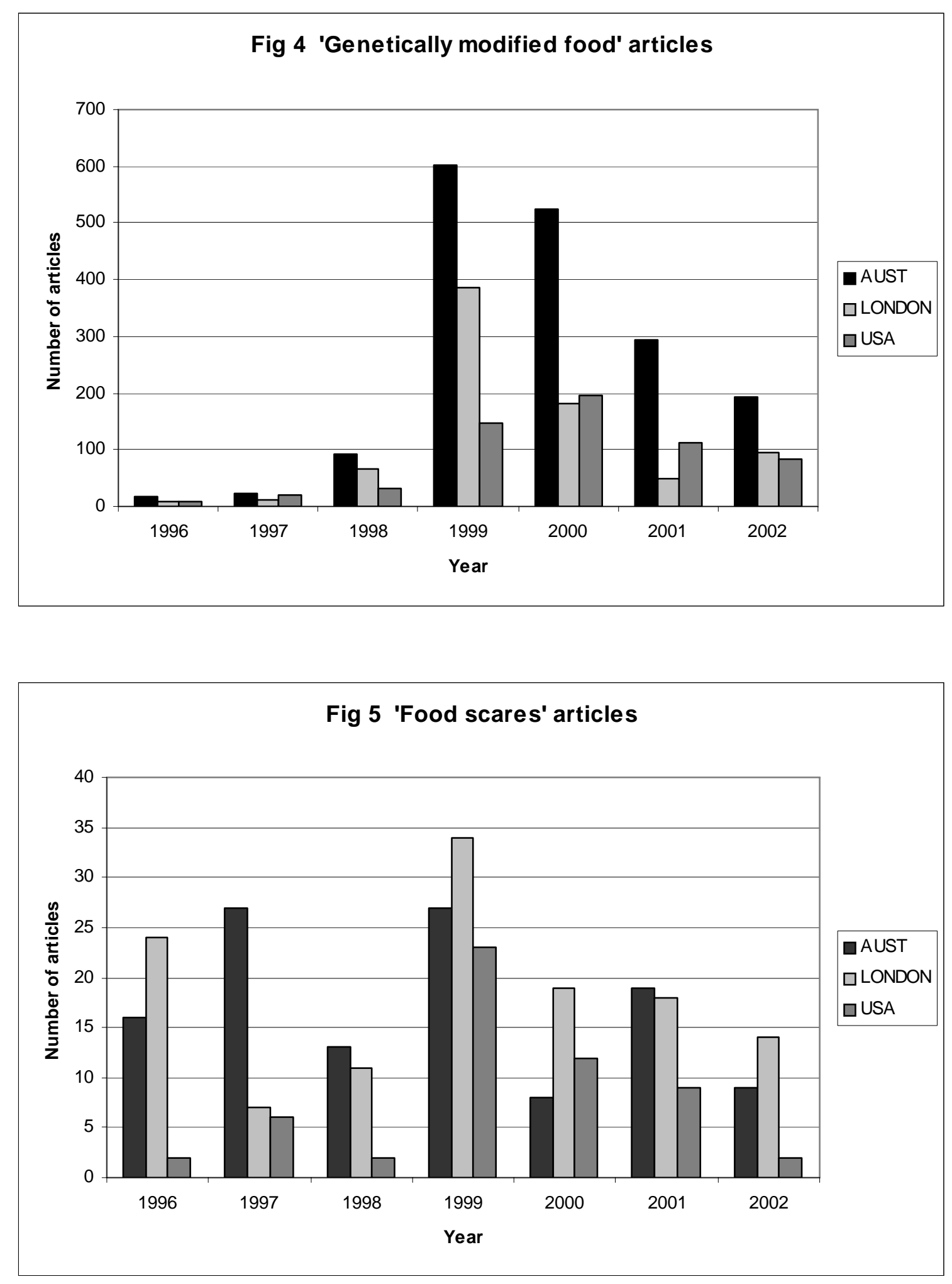

In contrast with the extremely low level of reporting of issues associated with environmental degradation in agriculture, organic food and agriculture and genetic engineering both featured prominently. However, consistent with the low level of reporting of environmental issues, the prevalence of articles on organic food (Figure 2) was several orders of magnitude higher than the prevalence of articles on organic agriculture (Figure 1). In terms of prevalence alone, the focus was very much on what 
potential readers may be eating rather than on how it was produced. There was also a clear trend over time with coverage of organics rising from its low base to a peak in 2000 and 2001 and then dropping slightly.

As Figures 3 and 4 show, the concept of genetically engineered foods was far more common in Australian newspapers than was genetic engineering, while the reverse was true of the London and US newspapers sampled. Reporting on genetic engineering and genetically modified foods, however, followed a consistent pattern, peaking approximately a year earlier than organics in 1999 and 2000, and thence dropping off somewhat more dramatically than did reporting on organics. While it is impossible to draw a direct causal link between heightened media scrutiny of the new biotechnologies, peoples' concerns regarding these technologies and their interest in organic foods, this pattern is at least consistent with such a proposition and deserves further analysis.

The level of reporting on food scares was low by comparison with organics and genetic engineering. Although this may have reflected low use of this specific term in articles that otherwise dealt with specific food scares such as the BSE crisis, what is important to note from Figure 5 is that there is no readily apparent correlation between the level of reporting on food scares and media interest in either organics or genetic engineering in Australia and the US. The London Times, by contrast, did appear to increase its reporting of food scares around about the same time that its interest in genetic engineering peaked, although it also appeared to sustain a more consistent interest in organic foods over the following few years.

It is, of course, dangerous to infer too much from the prevalence alone of articles on each topic. By itself, prevalence tells us nothing of the relative importance placed on different issues through practices such as positioning and presentation, nor the ways in which issues are interpreted and represented to the reader. This paper turns, therefore, to the framing of these issues and, in particular, the ways in which they were framed in relation to each other.

\section{Framing food, environment and health issues}

\section{Food scares}

The apparent lack of any direct causal relationship between the incidence of food scares and the level of media interest in either organic or genetically engineered foods is shown to be somewhat more complicated by an examination of the ways in which food scares were framed in British, US and Australian newspapers. A number of themes dominated the framing of food scares:

- $\quad$ the perception that the principal food-borne threat in Australia and the US was food poisoning or contamination caused by food producers, processors and/or retailers;

- $\quad$ the perceived freedom of Australia and the US from the level of food-borne risk associated with farming practices experienced in Europe and Britain;

- $\quad$ the status within Britain of genetic engineering as a food scare in its own right; and, 
- $\quad$ the dramatic contrast between public fears and anxieties as embodied in food scares and the claims of state food regulators that these fears were out of proportion with the level of risk determined by objective scientific assessment.

Often, these themes were drawn together as shown by the following quote from the Chicago Tribune (Goering, 1999: 1):

European countries, spooked by recent food scares from mad cow disease to products laced with cancer-causing dioxins, have in the last four months led an international charge away from transgenics, which environmental groups there have termed 'Frankenstein foods'.

This food scare induced charge away from transgenics was, in turn, credited with responsibility for the rapidly growing enthusiasm of the British public for organic food. The Times (London) reports that:

The controversy over genetically modified foods and multitudinous food scares have meant that ... Organic food sales have risen by 40 per cent for the second year running, and will be worth Pounds 546 million by the end of 1999 (and an estimated Pounds 1billion by 2001) ... Studies show that one in three people have bought organic food in the last three months (Teeman, 1999).

As will be elaborated in the sections below, apologists for the biotechnology industries regularly used print media in all three countries to promote the view that food scares related to genetic engineering and other industrial agriculture technologies are irrational and have cynically been manipulated by the organic food industry for its own commercial ends. In response, an alternative framing has also been presented in these newspapers that represents consumer demand for organic produce not as an irrational confusion of unrelated events but as a reasonable response to competing knowledge claims and to state and industry agencies that have not proven themselves trustworthy. In an article that otherwise parodied anti-GE protestors as earnest, but illinformed and confused, The London Times argued that the British government was not only losing the battle to convince the general public that genetic engineering offered significant benefits but would continue to do so because of its past record on these issues:

The problem for the government is that after a tortuous period of shillyshallying and double-talk, many previous food scares have proved to be well founded (Driscoll and Carr-Brown, 1999).

The erosion of trust in pubic agencies was extended to private firms seen to be pushing products with no discernable consumer benefits. Attempts by Monsanto, for example, to market transgenic crops in Europe were reported in the Chicago Tribune to coincide:

with a string of food scares that undermined confidence in big agriculture, as well as in government regulators who at the time downplayed the genuine human health risks of mad cow disease (Burns, 2002:1). 
From this perspective, consumers were rational to shun genetically modified foods promoted by the same governments and companies that had dismissed their fears in the past. Industrialized foods - whether the products of genetic engineering or inputintensive agriculture more generally-were believed to be as risky for their dependence on untrustworthy institutions as they were for the dependence on seemingly unnatural production processes.

\section{Genetic engineering and genetically modified foods}

The novelty of genetic engineering - together with its raft of highly controversial positive and negative implications - amplifies its perceived public significance and provides innumerable symbolic resources on which pro and anti-GE spokespeople may draw. Genetic engineering and genetically modified foods were framed variously as:

- $\quad$ scientific achievements newsworthy in their own right as examples of human progress and modernization;

- $\quad$ a focus of moral and environmental conflict to be reported on in an impartial manner little different to reporting of conflicts over, for example, animal experimentation, abortion or wildlife conservation;

- $\quad$ a source of personal and environmental risk with uncertain ecological and health implications including the possibilities of gene transfer and genetic contamination;

- $\quad$ a new agricultural and pharmaceutical revolution promising, on an international scale, to ease hunger and cure currently intractable diseases;

- $\quad$ a new agricultural revolution promising to increase production efficiencies and in which farmers must participate in order to maintain competitive advantage;

- $\quad$ an international trade dispute between, primarily, the United States and the European Union;

- $\quad$ a threat to democracy and the rights of farmers and consumers to decide for themselves whether or not to grow or ingest genetically modified organisms; and,

- $\quad$ the antithesis of anti-scientific irrationalism.

Of the framings listed above, by far the most prevalent among the newspapers sampled was genetic engineering as a focus of moral and environmental conflict, with protagonists themselves drawing, to varying degrees, on other framings such as personal and environmental risks, the promise of a revolution in food supply, and so on. Articles thus tended to draw on several framings at once within an overall framing of the article as a factual report on public debate. This melding of framings is illustrated in reports of a speech given by British Prime Minister Tony Blair to the Royal Society in London. According to Mr Blair:

to oppose scientific research [is] to retreat into a culture of unreason ... There is only a small band of people, I believe, who genuinely want to stifle informed debate ... But a small group can, as has happened in our country, destroy experimental crops before we can determine their environmental impact. I don't know what that research would have concluded. Neither do the protesters. But I want to reach my judgments after I have the facts and not before ... In GM crops I can find no serious 
evidence of health risks, but there are genuine and real concerns over biodiversity and gene transfer (Kite and Henderson, 2002).

Mr Blair's comments as quoted above are, of course, far more temperate than some of the rhetoric that has been published on genetic engineering and genetically modified foods. From 'miracle seeds' to 'mad scientists' and 'Frankenfoods', it is not difficult to find extravagant claims about both the benefits and dangers of the new biotechnologies and the hidden agendas and/or fundamental stupidity of both pro and opposition groups. Nor is it difficult to find such claims dressed up as scientifically reputable positions (see also Kleinman and Kloppenbug, 1991; Kloppenburg, 1991; Levidow, 1995). Dr Bruce Chassy, for example, assistant Dean for Biotechnology Outreach at the University of Champaign-Urbana suggests that reluctance to eat genetically modified foods stems from a pair of 'clinical conditions' he describes as 'food neurosis' and 'food psychosis' (O’Neill, 2001). According to Arthur Caplan, Professor of Bioethics at the University of Pennsylvania, those avoiding genetically modified food 'have become susceptible to bogeyman nightmares about cuckoo scientists run amok' (Stolberg, 2002: 16). It is notable, however, in taking a holistic view of reporting of conflict over genetic engineering and genetically modified foods that the vast majority of claims used relatively moderate language. This was especially the case outside of Britain, where direct protest actions such as destruction of GE trials were seen, like food scares, to be a particularly British phenomenon.

Reporting of conflict over genetic engineering in the US gave relatively little voice to opponents of the technology with conflict represented as a reflection of differences in the regulatory and institutional environments between the US and European Union. Even though a series of polls conducted by the Pew Initiative on Food and Biotechnology (2003) between 2001 and 2002 suggested that Americans were moreor-less evenly divided over the merits of biotechnologies and the reliability of food regulators, major US newspapers seemed to accept the assertions of pro-biotech lobby groups that opposition to GE was a peculiarly European 'hysteria'. According to the New York Times:

Genetic modification of food has been a relatively unquestioned phenomenon in the United States and Canada, with altered ingredients in a range of processed food from soft drinks to beer to breakfast cereals ...But its arrival [in Britain] set off alarms and united demonstrators from lapsed causes into a powerful protest movement against what they call 'Frankenstein food' and the large multinational companies promoting it. There is no government agency in Europe of the regulatory rigor of the United States Food and Drug Administration to build consumer confidence, and government approval can arouse as much suspicion as it can provide reassurance (Hoge, 1999).

In contrast, Australian reporting of conflict over genetic engineering was as notable for its focus on the threat posed by gene transfer to the rapidly growing organic food industry as for its focus on the threat posed to ecosystems and human health.

It is important to note that the interest of this paper lies not in the entire discursive field of genetic engineering but in those aspects that relate to the ordering of food production-consumption networks around concepts of sustainability. In this respect, it 
is worth reiterating that while one framing of genetic engineering was as a revolution in agriculture that would solve environmental problems and feed more people, this particular framing was secondary to the framing of GE as a focus for conflict over human safety and the morality of 'tampering with nature'. The environmental and humanitarian framing was also criticized (by opponents and proponents alike) for overstating and misrepresenting the benefits of genetic engineering as it was actually being applied. With the majority of commercial applications devoted to herbicide and insect resistance, it was entirely reasonable, many argued, for potential consumers to conclude that few tangible benefits would flow either to themselves or to the environment that might justify what they perceived as the risks of the technology. Nevertheless, the future potential of genetic engineering to develop products that incorporated more environmental and health attributes was frequently used to frame GE as an approach from which the benefits did ultimately outweigh the risks in a manner that framing GE as a revolution in agricultural efficiency and profitability would not. In light, however, of the future orientation of many of these benefits-and scepticism over the environmental benefits of herbicide and insect resistant cropsthe major impact of genetic engineering and genetically engineered foods on the mobilization of overtly sustainable production-consumption has generally been represented as a stimulus to growth in demand for organic and other certified GE-free foods. As the data presented earlier in this chapter on the prevalence of reporting on these issues shows, this appears to be a plausible conclusion.

\section{Organic food and agriculture}

As we have seen in the above sections, organic foods were constructed in the mass media often in terms of what they were not-genetically engineered or otherwise the products of industrialized agriculture. However, while the link between food scares, genetic engineering and organic food was strong, it was certainly not the only, or even dominant, framing of organic food. Organic food and agriculture were framed as:

- $\quad$ newsworthy in their own right as reputedly the fastest growing sector of the food and agriculture industries with significant potential for further market and export growth;

- $\quad$ a fashionable, high quality and tasty ingredient found increasingly both in the offerings of restaurants and retail outlets and in the diets of celebrities;

- $\quad$ the safe and natural alternative to conventionally grown foods tainted by scares over, among other things, chemical residues and genetically modified organisms;

- $\quad$ the solution to a raft of environmental problems caused by conventional farming and threatened by genetic engineering;

- $\quad$ a means of protecting the integrity and viability of traditional regional cuisines and farming communities, and of connecting urban consumers with those cuisines and communities;

- $\quad$ an industry that has cynically manipulated public fears despite offering products that themselves carry considerable risks for consumers;

- $\quad$ the focus of considerable scientific controversy over the real risks and benefits of organic food and farming practices.

Framing organic food and agriculture as an alternative to genetic engineering and other industrialized agricultural practices was common in the print media of all three 
countries. However, while the framing of organics as an alternative may conjure up a host of other identities and practices associated with so-called alternative lifestyles (vegetarianism, intentional communities, alternative economics and so on), there was also much to suggest that organics was constructed as increasingly mainstream. The framing of organic food and agriculture as a legitimate market segment and as a high quality ingredient established organics as a regular item for reporting and discussion quite independently of its status as an alternative to conventional agriculture. Lifestyle sections, in particular, devoted increasing space to organic foods over the sampling period in a manner that largely avoided the framing of organics as an alternative. The more overtly editorial nature of material presented in lifestyle sections also made for some important differences in the way organics was represented. With the overt expression of personal opinion and experience far more acceptable in this format than in news sections of the newspapers, a great many authors simply presented organic food as a product that was self-evidently superior to conventionally-grown foods in a number of ways. For a number of authors this was simply a matter of taste, but for others it was also a matter of safety, naturalness and environmental protection.

The evidence of mainstreaming apparent in this acceptance of organic food as a desirable high quality product was augmented by regular news articles on growth in the market for organic foods and on the increasingly diverse consumer base. The Chicago Tribune, for example, reported that sales of organic foods grew more than 20 percent per annum over the ten years leading up to 2001 when they were estimated at US\$9.3 billion, and were projected to increase to nearly US\$20 billion by 2005 (Kaiser, 2002). According to Paddy Spence, CEO of a market research group specialising in natural foods. 'as organic and natural foods get more distribution points in supermarkets and other retail outlets, they will become even more mainstream' (Condor, 2002).

As the most visible alternative to industrially produced foodstuffs the industry attracted considerable attention and criticism. Framing organic foods as themselves risky, and the organic food and agriculture industry as cynical and exploitative, critics attempted to debunk positive beliefs towards organics and suggest it is in consumers' own interest to avoid organic products. Claiming the mantle of scientific objectivity, critics charged the organic industry with:

- $\quad$ promoting farming practices that:

o can not produce enough food to feed growing populations without massive clearing of the world's remaining forests;

o deny livestock veterinary medicines essential to their health and welfare;

o increase the risk to consumers of ingesting microbiological pathogens;

o have no proven environmental benefits.

- $\quad$ overstating differences in the nutritional content and levels of contamination between conventionally and organically grown foods;

- $\quad$ manipulating public fears in order to promote their own economic interests.

As with genetic engineering, there was no shortage of extravagant and colourful language. According to a representative of the Institute of Public Affairs (a politically conservative thinktank based in Melbourne) writing in the Brisbane Courier Mail: 
YOU have to hand it to the greens. They really know how to generate unnecessary public alarm. Their latest triumph has been with genetically modified crops, or 'Frankenfoods' as they call them. No doubt most 'poofood' farmers are responsible people, but in their desire to make a profit, it is a fair bet that some are cutting corners and putting public health at risk. After all, greens always claim that this is what large corporations are doing (Brunton, 2000: 30).

Accompanying the increase in articles attempting to debunk the organic industry over the sampling period were a number of articles questioning the integrity and motivations of the organic industry's critics. Suggesting criticism to be part of an orchestrated campaign to discredit the organic industry, the Chicago Tribune stated that:

A recent front-page headline in The Daily Mail in London warned, 'Organic Mushrooms Were Contaminated With Deadly Bacteria.' Not until the fifth paragraph did the reader learn that the headline was false, that the E. coli found in the mushrooms was not E. coli 0157:H7, which is deadly, but the generic variety, which is not ... These weren't the first false charges. Last year, according to The Guardian, the 'agri-industrial food establishment' mounted 'an ill-informed and unjustified smear campaign' that tried to link organic food to the hazardous form of E. coli. The thriving organic movement in Britain must have agribusiness and biotech industry worried (Burros, 2000: 3B).

Despite the confusion that such claims and counter-claims may be expected to invoke, organic food was the only signifier consistently linked with environment, healthiness and quality within the print media surveyed. As simplistic a position as it may seem, the overwhelming impression to be gained from this analysis is that organic foods have been constructed in the print media as natural while their competitors have not.

\section{Discussion}

Mass media reporting of issues related to the environmental and safety attributes of food over the sampling period was characterized by a polarized debate in which organic and genetically-modified foods were pitched against each other as the respectively 'natural' and 'agro-industrial' representatives of everything that was good and bad within the food system. Despite contradictory views on the rationality of food scares - and the linking of new technologies such as genetic engineering to the arguably rather different practices responsible for existing microbiological food hazards-such scares were attributed the primary causal role behind anti-GE and proorganic sentiments and consumption behaviours.

The fact that food scares frequently were framed as responsible for anti-GE and proorganic sentiment among consumers does not, in itself, prove that such a relationship exists. Certainly, it seems unlikely that food scares would not have contributed in some measure to increasing public concern with food production and regulation. However, there is no compelling evidence that media reporting of food-borne hazards has been the primary agent responsible for either the level of concern over genetic 
engineering or the growth of interest in organic foods. As Figure 5 showed, there has, in fact, been very little correlation even within the media between reporting of food scares and reporting of organics and genetic engineering. The point here is not that the threat of food-borne hazards is irrelevant but that a simple linear relationship between microbiologically-based food scares, declining faith in food regulatory agencies, uncertainty over the long-term implications of the new biotechnologies, and rapid growth in the market for certified organic food is unlikely. At the very least, this fails to consider: poor consumer understanding of organic certification and labelling systems; widespread confusion over what the term organic means; the importance of non-safety related food quality attributes such taste and provenance in the organic market; non-safety related concerns over genetic engineering such as the concentration of intellectual property, destruction of biodiversity and homogenization of food production and consumption cultures; and, in Australia at least, a widespread belief that conventionally-produced foods are reasonably safe (Lockie, 2002; Lockie et al., 2002).

By linking food scares to a simplified binary between the organic/natural and the GE/agro-industrial, media-based discourses on food and sustainability were created and reproduced in which the multiple approaches taken by agriculturalists to the pursuit of sustainability and food quality were largely invisible. Relatively little media discussion of food, therefore, might have been seen to promote improved public understanding of agriculture and environmental issues. This has obvious enough implications for those promoting conservation farming, integrated pest management, whole farm planning, or any of a host of other non-organic and nonbiotech agri-environmental measures. Whatever their particular agroecological merits and appeal, or otherwise, to farmers, existing media discourses would do little to help create market values and incentives for food produced using these practices. The implications of this binary for promoters of any of the new biotechnologies are also obvious enough. Regardless of the reasons for their introduction, any foods produced using GE and other biotechnologies are likely to be seen as threatening and undesirable. Even for organic producers, the simplicity of this binary must be seen as potentially problematic to the extent that the construction of organic food consumption as a defensive mechanism against food scares obscures alternative constructions of quality based on taste, nutrition, tradition and so on. The latter constructions tend to favour relatively small-scale production and complex agroecologies over the more industrialized operations that are coming to dominate organic production (see Guthman, 2000, 2004). But if the sole reason for consuming organic food is to avoid the ingestion of synthetic chemical residues, there is no reason not simply to substitute synthetic chemicals and fertilizers with naturallyderived pesticides and fertilizers within otherwise conventional production systems.

There are those, of course, who regard simplified framings of organics and biotech as desirable and useful. The data reported above showed evidence of a number of groups who sought to utilize media discourses in order to shape food productionconsumption networks in particular ways through the dissemination of emotive signifiers and arguably misleading information. What is most interesting here is not the empirical veracity of the various claims and counter-claims made about organics and genetic engineering but the contradictory, and perhaps unforeseen, outcomes of this contestation. Even within the biotechnology sector a critique had begun to emerge of the negative consequences-in terms of heightened public mistrust and 
opposition-flowing from the tendency of proponents to overstate the potential shortterm benefits of GE and other innovations. It seems likely that the exaggerated negative stereotyping of political opponents often accompanying such polemics only added to this mistrust and opposition; particularly given that negative stereotyping was directed not only towards 'the greens' and other political groups but at the larger body of food consumers who were described by some as too neurotic, hysterical and intellectually vulnerable to make their own informed decisions. At the same time, it is possible to speculate that media attention on the strong market performance of the organic industry and its ability to draw on discourses of economic growth and free enterprise may-despite the misgivings of many participants that this represents the 'conventionalization' of the sector-have helped to legitimize campaigns against GE and other forms of agro-industrialization.

\section{Conclusion}

There is a clear disjuncture between those discourses of sustainability that dominate agriculture and agricultural science and those that dominate the mass media. While agriculture in the broadest sense is characterized by a number of competing approaches to sustainability (see Pretty, 1998), media discourses often present sustainability simply as a choice between organic agriculture and the industrialized, genetically modified and chemical intensive alternative of conventional agriculture. This simplification of sustainability discourse, and the focus on aspects of food related to food safety and nutrition, cannot be considered surprising given the basic journalistic principle of helping audiences sift through and understand the vast amount of information to which they are exposed by focussing on what is most relevant to them as individuals (Hannigan, 1995). Even those appeals to the authority of science found in media discourses seldom do justice to the complexity of scientific debate on sustainability. However, the point here is not to imply criticism of the mass media, but to show that despite the multitudinous ways in which we might approach agricultural sustainability, organic food and agriculture has been the only approach consistently represented within media discourses as the means to promote healthier environments and people. Other approaches, ranging from Integrated Pest Management to Conservation Farming, either are absent from these discourses or are represented as antithetical to sustainability (by, for example, using chemicals rather than 'natural' means to reduce soil erosion).

There is, of course, more to knowledge and power than those aspects of discourse reflected in the mass media. In the case of food, it is impossible to ignore a range of influences ranging from the research agendas of scientific agencies to, farming culture, government policy, and so on. Despite this, the pervasiveness of the mass media and the discourses circulating through it are reflected both in confusion among many food consumers over the attributes of organic, conventional and geneticallyengineered foods (Lockie, 2002; Lockie et al., 2002) and, as media articles themselves suggest, a growing lack of trust among consumers in regulatory agencies seen to promote industry over public interests. Contestation over the meaning and operationalization of sustainability seems thus to have had what may appear at first glance contradictory results. For at the same time that the plethora of competing claims have contributed to confusion, ambivalence and a sense of powerlessness 
among some, they have provided fertile ground for organic food as a straightforward and holistic signifier of safety, quality and responsibility to stake its own claim.

\section{References}

Barr, N. and J. Cary (1992). Greening a Brown Land: The Australian Search for Sustainable Land Use. Melbourne: Macmillan.

Brunton, R. (2000). “Turning tables on monster makers.” Courier Mail, Saturday 5 August, SECTION: FEATURES: 30.

Burns, G. (2002). "Europe shows little taste for U.S. biotech crops.” Chicago Tribune, October 30, 2002 Wednesday, NORTH SPORTS FINAL EDITION, SECTION: Business: 1.

Burros, M. (2000). "Green Britain: Organics have gained a mainstream following in England.” Chicago Tribune, October 18, 2000 Wednesday, NORTHWEST EDITION, SECTION: Good Eating: 3B.

Condor, B. (2002). "The market for organics blossoms.” Chicago Tribune, October 13, 2002 Sunday, CHICAGOLAND FINAL EDITION, SECTION: Q: 1.

Corner, J. and K. Richardson (1993). "Environmental communication and the contingency of meaning: A research note.” In A. Hansen (ed.), The Mass Media and Environmental Issues (pp. 222-233). Leicester: Leicester University Press.

Driscoll, M. and J. Carr-Brown (1999). "What's eating us?” Sunday Times (London), February 21, 1999, Sunday SECTION: Features.

Foucault, M. (1980). Power/knowledge. Brighton: Harvester.

Goering, L. (1999). "Genetic stew boils in Brazil: South American giant struggles to decide whether to plant a genetically modified soy crop, a risky proposition." Chicago Tribune, August 5, 1999 Thursday, CHICAGO SPORTS FINAL EDITION, SECTION: NEWS: 1.

Guthman, J. (2000). "Raising organic: An agro-ecological assessment of grower practices in California.” Agriculture and Human Values 17: 257-266.

Guthman, J. (2004). "The trouble with 'organic lite' in California: A rejoinder to the ‘conventionalisation’ debate.” Sociologia Ruralis 44(3): 301-316.

Hannigan, J. (1995). Environmental Sociology: A Social Constructionist Approach. London: Routledge.

Haralambos, M., R. van Krieken, P. Smith and M. Holborn (1996). Sociology: Themes and Perspectives, Australian Edition. Sydney: Longman.

Hoge, W. (1999). "Britons skirmish over genetically modified crops.” The New York Times, August 23, 1999, Monday, Late Edition - Final, SECTION: Section A: 3.

Kaiser, R. (2002). "Farmers make a natural progression: Organic trend continues its strong growth.” Chicago Tribune, October 13, 2002 Sunday, CHICAGOLAND FINAL EDITION, SECTION: Business: 1.

Kite, M. and M. Henderson (2002). "GM demonstrators are ignorant, says Blair.” The Times (London), May 24, 2002, Friday, SECTION: Home news.

Kleinman, D. and J. Kloppenburg jun (1991). "Aiming for the discursive high ground: Monsanto and the biotechnology controversy." Sociological Forum 6(3): 427447.

Kloppenburg, J. jun (1991). "Alternative agriculture and the new biotechnologies.” Science as Culture 4: 482-506.

Law, J. (1994). Organizing modernity. Oxford: Blackwell. 
Levidow, L. (1995). “Agricultural biotechnology as clean surgical strike.” Social Text 13(3): 161-180.

Lockie, S. (2002). “'The invisible mouth': Mobilizing 'the consumer' in food production-consumption networks.” Sociologia Ruralis 42(2): 278-294.

Lockie, S., K. Lyons, G. Lawrence and K. Mummery (2002). “Eating 'green': Motivations behind organic food consumption in Australia." Sociologia Ruralis 42(1): 20-37.

Miller, M. and B. Riechert (2000). "Interest group strategies and journalistic norms: News media framing of environmental issues.” In S. Allan, B. Adam and C. Carter (eds.) Environmental Risks and the Media (pp. 45-54). London: Routledge.

O’Neill, G. (2001). “The hidden agenda.” Sunday Herald Sun (Melbourne) January 21, 2001, Sunday, SECTION: NEWSFRONT: 48.

Pew Initiative on Food and Biotechnology (2003). Public Sentiment About Genetically Modified Food [Accessed online at http://pewagbiotech.org/polls/ 26 August 2004].

Pretty, J. (1998). The Living Land: Agriculture, Food and Community Regeneration in Rural Europe. London: Earthscan.

Stolberg, S. (2002). "It's Alive! It's Alive!” The New York Times, May 5, 2002, Sunday, Late Edition - Final, Section 4: 16.

Teeman, T. (1999). "The most important issue of our time." The Times (London), November 6, 1999, Saturday, SECTION: Features

Vanclay, F. (1992). "The social context of farmers' adoption of environmentally sound farming practices.” In G. Lawrence, F. Vanclay and B. Furze (eds.), Agriculture, Environment and Society: Contemporary Issues for Australia (pp. 94-121). Melbourne: Macmillan. 